\title{
Streptomyces misionensis PESB-25 Produces a Thermoacidophilic Endoglucanase Using Sugarcane Bagasse and Corn Steep Liquor as the Sole Organic Substrates
}

\author{
Marcella Novaes Franco-Cirigliano, ${ }^{1}$ Raquel de Carvalho Rezende, ${ }^{1}$ \\ Mônica Pires Gravina-Oliveira, ${ }^{1}$ Pedro Henrique Freitas Pereira, ${ }^{1}$ \\ Rodrigo Pires do Nascimento, ${ }^{2}$ Elba Pinto da Silva Bon, ${ }^{3}$ Andrew Macrae, ${ }^{1}$ \\ and Rosalie Reed Rodrigues Coelho' \\ ${ }^{1}$ Departamento de Microbiologia Geral, Instituto de Microbiologia Paulo de Góes, Centro de Ciências da Saúde (CCS), Universidade \\ Federal do Rio de Janeiro (UFRJ), Avenida Carlos Chagas Filho 373, Bloco I, Laboratório 055, 21941-902 Rio de Janeiro, RJ, Brazil \\ ${ }^{2}$ Departamento de Engenharia Bioquímica, Escola de Química, Centro de Tecnologia (CT), Universidade Federal do Rio de Janeiro \\ (UFRJ), Avenida Athos da Silveira Ramos 149, Bloco E, sala 203, 21941-909 Rio de Janeiro, RJ, Brazil \\ ${ }^{3}$ Departamento de Bioquímica, Instituto de Química, Centro de Ciências Matemáticas e Natureza (CCMN), Universidade Federal do \\ Rio de Janeiro (UFRJ), Avenida Athos da Silveira Ramos 149, Bloco A, sala 539, 21941-909 Rio de Janeiro, RJ, Brazil
}

Correspondence should be addressed to Rodrigo Pires do Nascimento; rodrigopires@eq.ufrj.br

Received 1 October 2012; Revised 8 January 2013; Accepted 4 February 2013

Academic Editor: Divya Prakash

Copyright (C) 2013 Marcella Novaes Franco-Cirigliano et al. This is an open access article distributed under the Creative Commons Attribution License, which permits unrestricted use, distribution, and reproduction in any medium, provided the original work is properly cited.

\begin{abstract}
Streptomyces misionensis strain PESB-25 was screened and selected for its ability to secrete cellulases. Cells were grown in a liquid medium containing sugarcane bagasse (SCB) as carbon source and corn steep liquor (CSL) as nitrogen source, whose concentrations were optimized using response surface methodology (RSM). A peak of endoglucanase accumulation $\left(1.01 \mathrm{U} \cdot \mathrm{mL}^{-1}\right)$ was observed in a medium with SCB $1.0 \%(\mathrm{w} / \mathrm{v})$ and CSL $1.2 \%(\mathrm{w} / \mathrm{v})$ within three days of cultivation. S. misionensis PESB-25 endoglucanase activity was thermoacidophilic with optimum $\mathrm{pH}$ and temperature range of 3.0 to 3.6 and $62^{\circ}$ to $70^{\circ} \mathrm{C}$, respectively. In these conditions, values of $1.54 \mathrm{U} \mathrm{mL}^{-1}$ of endoglucanase activity were observed. Moreover, $\mathrm{Mn}^{2+}$ was demonstrated to have a hyperactivating effect on the enzyme. In the presence of $\mathrm{MnSO}_{4}(8 \mathrm{mM})$, the enzyme activity increased threefold, up to $4.34 \mathrm{U} \cdot \mathrm{mL}^{-1}$. $\mathrm{Mn}^{2+}$ also improved endoglucanase stability as the catalyst retained almost full activity upon incubation at $50^{\circ} \mathrm{C}$ for $4 \mathrm{~h}$, while in the absence of $\mathrm{Mn}^{2+}$, enzyme activity decreased by $50 \%$ in this same period. Three protein bands with endoglucanase activity and apparent molecular masses of 12, 48.5 and $119.5 \mathrm{kDa}$ were detected by zymogram.
\end{abstract}

\section{Introduction}

Enzymatic hydrolysis of cellulose is a challenge worldwide, because currently we lack inexpensive and efficient enzymes to hydrolyse the 1.5 trillion tons of cellulose produced annually [1]. Enzyme blends and optimization are required to speed up enzymatic hydrolysis to make the process commercially viable. Cellulose is a homopolymer of $\beta-1,4$ linked glucose units presenting both amorphous and crystalline regions. Its hydrolysis is carried out by endo- $\beta-1,4$-glucanase (EC 3.2.1.4), which cleaves internal $\beta$-1,4-glycosidic bonds at random positions and forms insoluble reducing sugars, and by exo- $\beta$-1,4-glucanase (EC 3.2.1.91) that hydrolyses cellulose from its reducing and nonreducing ends releasing soluble reducing sugars with prevalence of cellobiose. The enzyme $\beta$-glucosidase (EC 3.2.1.21) converts cellobiose into glucose monomers [2]. An increase in the formation of free reducing and nonreducing ends from endo-acting cellulases 
could speed up the action of the exoglucanases and the total cellulose hydrolysis process. A significant amount of research on new endoglucanases has been done $[3,4]$.

Cellulolytic organisms are ubiquitous in nature. They are mostly bacteria and fungi, aerobic or anaerobic, and mesophilic or thermophilic. Actinomycetes, which are Grampositive filamentous soil bacteria, are well known for their ability to decompose complex molecules, particularly the lignocellulose components, which make them important agents in decomposition processes [5]. They have also been shown to produce thermostable cellulases, with alkalophilic and acidophilic characteristics $[6,7]$. The work that has been done in our laboratory with strains from the Streptomyces genus indicates that endoglucanase activity is predominant in these bacterial cellulases. In previous studies from our laboratory, we reported that the culture supernatant of $S$. malaysiensis AMT-3, S. drozdowiczii M-7A, and S. viridobrunneus SCPE09 presented endoglucanase activity with optimal $\mathrm{pH}$ in the range of 4.0 to 5.0 , optimal temperature around $50^{\circ} \mathrm{C}$ and molecular masses, according to zymogram analyses, in the range of 37 to $178 \mathrm{kDa}$ [8-10].

This study investigated cellulase production by an actinobacterial strain, S. misionensis PESB-25. Experimental design was performed to optimize endo- $\beta$-1,4-glucanase production using SCB as the main carbon source and CSL as nitrogen source. As seen before, these low-cost materials can be suitable for cellulases production [8-10]. The electrophoretic profiles of extracted enzymes were determined by zymogram analyses. Enzymatic activity was investigated over a range of $\mathrm{pH}$ and temperature values in the culture supernatants (crude enzyme preparation). The effect of metal ions, most importantly $\mathrm{Mn}^{2+}$, on the endoglucanase activity and stability was also evaluated.

\section{Materials and Methods}

2.1. Microorganism Screening, Preservation, and Cultivation. Streptomyces misionensis PESB-25 was collected from a sugarcane crop soil in the State of Pernambuco, Brazil. The dilution plate technique was used for the isolation of the bacterial strain, which was selected as cellulolytic via its cultivation on solid medium containing carboxymethylcellulose low viscosity $\left(\mathrm{CMC}_{\mathrm{lw}}\right)$ as carbon source followed by the identification of the CMC-degrading zones using the Congo red dye [11]. Spore suspensions were prepared according to Hopwood and colleagues [12] after cultivation at $28^{\circ} \mathrm{C}$ for 15 days in yeast extract-malt extract-agar medium [13]. Spores were maintained in $20 \%(\mathrm{v} / \mathrm{v})$ glycerol at $-20^{\circ} \mathrm{C}$.

\subsection{Molecular Identification of Bacterial Strain PESB-25.} Genomic DNA was extracted using the method described by Kurtzman and Robnett [14]. PCR amplification of the rrs gene was carried out using the GoTaq Green Master Mix kit (Promega Corporation), with primers 27F [15] and 1541R [16], in a thermal cycler model Gene Amp PCR System 9700 (Applied Biosystems). Amplified fragments were purified using the Illustra GFX PCR DNA and Gel Band Purification kit (GE Healthcare) and sequenced directly using ABI Prism dye terminator cycle sequencing reaction kit (Applied Biosystems) in an automatic sequencer (ABI model 3730; Applied Biosystems). The sequence of $r r s$ gene obtained was compared with sequences online at the Ribosomal Database Project (RDP) release 10 [17] and GenBank [18] using the NCBI (The National Center for Biotechnology Information) basic local alignment search tool, BLAST (http://blast.ncbi.nlm.nih.gov/Blast.cgi) [19].

\subsection{Endoglucanase Production Using Experimental Design.} Streptomyces misionensis PESB-25 was cultivated in liquid medium with SCB and CSL as the main carbon and nitrogen sources, respectively. SCB consists of $43.8 \%$ cellulose, $25.8 \%$ hemicellulose, $22.1 \%$ lignin, $6.1 \%$ extractives, and $1.4 \%$ ash [20]. It contains, approximately, $45.3 \%$ carbon and $0.5 \%$ nitrogen [21]. CSL is a major by-product of the corn wetmilling industry and contains $47 \%$ crude protein, $26 \%$ lactic acid, $7.8 \%$ phytic acid, $2.5 \%$ reducing sugars (as dextrose), and $17 \%$ ash, total nitrogen being $7.5 \%$ [22].

Response surface methodology (RSM) was used as a tool for the optimization of SCB and CSL concentrations (independent variables) in the range indicated in Table 1. Endoglucanase activity $\left(\mathrm{U} \cdot \mathrm{mL}^{-1}\right)$ was the dependent variable. A $2^{2}$ central composite rotational design (CCRD) was used to design experiments.

Cultivations were carried out in $125 \mathrm{~mL}$ Erlenmeyer flasks containing $25 \mathrm{~mL}$ of mineral salts solution [23] (in $\mathrm{g} \cdot \mathrm{L}^{-1}$ : $\mathrm{NaCl}, 2.0 ; \mathrm{KH}_{2} \mathrm{PO}_{4}, 3.0 ; \mathrm{K}_{2} \mathrm{HPO}_{4}, 6.0 ; \mathrm{MgSO}_{4} \cdot 7 \mathrm{H}_{2} \mathrm{O}, 0.5$; $\left.\mathrm{CaCl}_{2}, 0.05\right)$, supplemented with a trace element solution [13] (in $\mathrm{g} \cdot \mathrm{L}^{-1}: \mathrm{CuSO}_{4} \cdot 5 \mathrm{H}_{2} \mathrm{O}, 6.4 ; \mathrm{ZnSO}_{4} \cdot 7 \mathrm{H}_{2} \mathrm{O}, 1.5 ; \mathrm{FeSO}_{4} \cdot 7 \mathrm{H}_{2} \mathrm{O}$, 1.1; $\mathrm{MnCl}_{2} \cdot 4 \mathrm{H}_{2} \mathrm{O}, 7.9$ ), with SCB and CSL at the relevant concentrations. The medium start $\mathrm{pH}$ was adjusted to 7.0. The growth medium was inoculated with $25 \mu \mathrm{L}$ of a spore suspension $\left(10^{9}\right.$ spores $\left.\cdot \mathrm{mL}^{-1}\right)$ and incubated at $28^{\circ} \mathrm{C}$, under agitation $(200 \mathrm{rpm})$, for 3 days. The cultures were filtered through glass microfiber filter (Millipore), and the culture supernatant (crude enzyme preparation) was used for endoglucanase activity determination.

2.4. Standard Endoglucanase Activity Assay. Endoglucanase activity was determined by measuring the release of reducing sugars in a reaction mixture containing $0.5 \mathrm{~mL}$ of the crude enzyme preparation and $0.5 \mathrm{~mL}$ of $\mathrm{CMC}_{\mathrm{lw}}$ (SIGMA) $4.0 \%$ $(\mathrm{w} / \mathrm{v})$ solution in sodium citrate buffer $50 \mathrm{mM}(\mathrm{pH} 4.8)$ incubated at $50^{\circ} \mathrm{C}$ for $10 \mathrm{~min}$. Reducing sugars were assayed by the dinitrosalicylic acid method [24]. One unit (IU) of endoglucanase activity corresponded to the formation of $1 \mu \mathrm{mol}$ of reducing sugars equivalent per minute under the assay conditions [25].

\subsection{Effect of $p H$, Temperature, and Ions on the Enzyme Activity} and Stability. To study the effect of $\mathrm{pH}$ and temperature on the supernatants endoglucanase activity, a CCRD $2^{2}$ was used. In the 12 experiments which were carried out, the temperature ranged from $40^{\circ}$ to $70^{\circ} \mathrm{C}$ and the $\mathrm{pH}$ values from 3.0 to 7.0 as shown in Table 3. Citrate buffer $(50 \mathrm{mM})$ was used for $\mathrm{pH} 3.0,3.6$ and 5.0 and phosphate $(50 \mathrm{mM})$ for $\mathrm{pH} 6.4$ and 7.0 [26]. Statistical analysis of the results was performed using 
TABLE 1: Observed and predicted values of endoglucanase activity for the independent variables SCB and CSL concentrations used in central composite rotational design (CCRD), from the crude enzyme extract of Streptomyces misionensis PESB-25.

\begin{tabular}{lcccc}
\hline Run & SCB $(\% \mathrm{w} / \mathrm{v}) /$ Coded level & CSL $(\% \mathrm{w} / \mathrm{v}) /$ Coded level & $\begin{array}{c}\text { Endoglucanase activity } \\
\left(\mathrm{U}_{\mathrm{mL}}{ }^{-1}\right) \text { Observed }\end{array}$ & $\begin{array}{c}\text { Endoglucanase activity } \\
\left(\mathrm{U}_{\mathrm{mL}}^{-1}\right) \text { Predicted }^{*}\end{array}$ \\
\hline 1 & $0.65(-1)$ & $0.77(-1)$ & $0.95 \pm 0.11$ & 0.91 \\
2 & $1.35(+1)$ & $0.77(-1)$ & $0.72 \pm 0.005$ & 0.67 \\
3 & $0.65(-1)$ & $1.63(+1)$ & $0.86 \pm 0.003$ & 0.85 \\
4 & $1.35(+1)$ & $1.63(+1)$ & $0.98 \pm 0.038$ & 0.96 \\
5 & $0.5(-1.41)$ & $1.2(0)$ & $0.93 \pm 0.022$ & 0.95 \\
6 & $1.5(1.41)$ & $1.2(0)$ & $0.83 \pm 0.032$ & 0.86 \\
7 & $1.0(0)$ & $0.6(-1.41)$ & $0.66 \pm 0.003$ & 0.71 \\
8 & $1.0(0)$ & $1.8(1.41)$ & $0.87 \pm 0.024$ & 0.88 \\
9 & $1.0(0)$ & $1.2(0)$ & $1.03 \pm 0.016$ & 1.01 \\
10 & $1.0(0)$ & $1.2(0)$ & $1.03 \pm 0.044$ & 1.01 \\
11 & $1.0(0)$ & $1.00 \pm 0.003$ & 1.01 \\
\hline
\end{tabular}

The statistical analysis of the results was performed using the software Design Expert 7.0 (trial version).

*Values are based on Mean \pm SD of 3 individual observations.

the software Design Expert 7.0 (trial version), and response surface graphics were plotted with STATISTICA 7.0 (trial version).

The influence of sodium, calcium, potassium, and barium ions in the chloride form and copper, magnesium, cobalt, manganese, and iron in the sulfate form on the endoglucanase activity was done by the addition of the relevant salts at $2 \mathrm{mM}$ final concentration in the enzyme activity assay using the previously determined optimal conditions for $\mathrm{pH}$ and temperature. The effect of $\mathrm{Mn}^{2+}$ was studied using at final concentrations of $1,2,4,8$, and $10 \mathrm{mM}$.

Endoglucanase thermal stability was evaluated at $65^{\circ} \mathrm{C}$ and $50^{\circ} \mathrm{C}$ upon incubation at different time intervals. Stability experiments were also performed in the presence of $\mathrm{MnSO}_{4}$ $(8 \mathrm{mM}$ or $16 \mathrm{mM})$ in mixtures with $1.5 \mathrm{~mL}$ of the crude enzyme plus $1.5 \mathrm{~mL}$ of $\mathrm{MnSO}_{4}$ solutions. In all cases, residual enzymatic activity was assayed at optimal conditions for $\mathrm{pH}$ and temperature, taking into account the relevant enzyme dilutions.

2.6. Zymogram of Endoglucanase Activity. The culture supernatants from optimized growth conditions were analyzed by electrophoresis on denaturing $10 \%$ sodium dodecyl sulphate (SDS)-polyacrylamide gel added of copolymerized $\mathrm{CMC}_{\mathrm{lw}}$ (SIGMA) $0.2 \%(\mathrm{w} / \mathrm{v})$ as the zymogram substrate. Electrophoresis was performed at constant voltage $(100 \mathrm{~V})$ at $4^{\circ} \mathrm{C}$ for $3 \mathrm{~h}$ followed by incubation with Triton $\mathrm{X}-100$ sodium acetate $1.0 \%$ buffer for $30 \mathrm{~min}$ in ice bath for SDS removal. The detection of protein bands with endoglucanase activity was performed by incubating gels at $50^{\circ} \mathrm{C}$ and $\mathrm{pH}$ 4.8 (sodium citrate buffer $50 \mathrm{mM}$ ) for $30 \mathrm{~min}$, followed by the gel immersion in Congo red $0.1 \%(\mathrm{w} / \mathrm{v})$ for $10 \mathrm{~min}$ and washing with $\mathrm{NaCl} 1 \mathrm{M}$ until the visualization of the enzyme bands [27]. The molecular masses of the enzyme bands seen in gels were estimated by comparing their position in the gel with a molecular mass ladder using standard molecular masses ranging from 12 to $225 \mathrm{kDa}$ (Full-Range RainbowGE Healthcare), which was run along with the sample and photographed before Congo red staining.
TABLE 2: Statistical ANOVA for the model of endoglucanase production at different levels of concentrations of SCB and CSL.

\begin{tabular}{lccccc}
\hline $\begin{array}{l}\text { Source of } \\
\text { variations }\end{array}$ & $\begin{array}{c}\text { Sum of } \\
\text { squares }\end{array}$ & $\begin{array}{c}\text { Degrees of } \\
\text { freedom }\end{array}$ & $\begin{array}{c}\text { Mean } \\
\text { square }\end{array}$ & $F$ value & $\begin{array}{c}P \text { value } \\
(\text { prob }>F)^{\mathrm{a}}\end{array}$ \\
\hline Model & 0.13 & 5 & 0.03 & 11.74 & 0.01 \\
Residual & 0.01 & 5 & 0.002 & & \\
Lack of fit & 0.01 & 3 & 0.003 & 2.08 & 0.34 \\
Pure error & 0.003 & 2 & 0.001 & & \\
\hline Total & 0.14 & 10 & & &
\end{tabular}

${ }^{a}$ Statistically significant at $90 \%$ of confidence level; $R^{2}=0.84$.

\section{Results and Discussion}

The sequencing of $r r s$ gene resulted in a 1491 base sequence which was $100 \%$ similar to Streptomyces misionensis Type Strain NRRL B-3230, and as such PESB-25 was putatively identified as a strain belonging to $S$. misionensis. The sequence obtained was submitted to the GenBank database (GenBank ID: JN869290). S. misionensis Type Strain NRRL B-3230 was isolated in Misiones, Argentina, and it produces misionin, an antibiotic active against phytopathogenic fungi, including Helminthosporium and Alternaria [28]. Strains from this species have been cited in the literature confirming their presence in certain soils [29] and their antibiotic production capacity [30]; however, there have been no reports that strains of this species can be cellulolytic.

The use of RSM and CCRD tools for the optimization of Streptomyces misionensis endoglucanase production resulted in enzyme activity accumulation in the range of 0.67 to $1.03 \mathrm{U} \cdot \mathrm{mL}^{-1}$ (Table 1). The fitted response surface for the production of endoglucanase is given in Figure 1. Best results were obtained at center-point conditions, with SCB $1.0 \%$ $(\mathrm{w} / \mathrm{v})$ and CSL $1.2 \%(\mathrm{w} / \mathrm{v})$, although results obtained in some other concentrations were not so different (e.g., 1.35\% SCB and $1.03 \%$ CSL). The interaction effect evident between SCB and CSL could be related to the $\mathrm{C}: \mathrm{N}$ proportion necessary for microbial growth, and consequently better enzyme production. The relevant regression equations, resulting from 


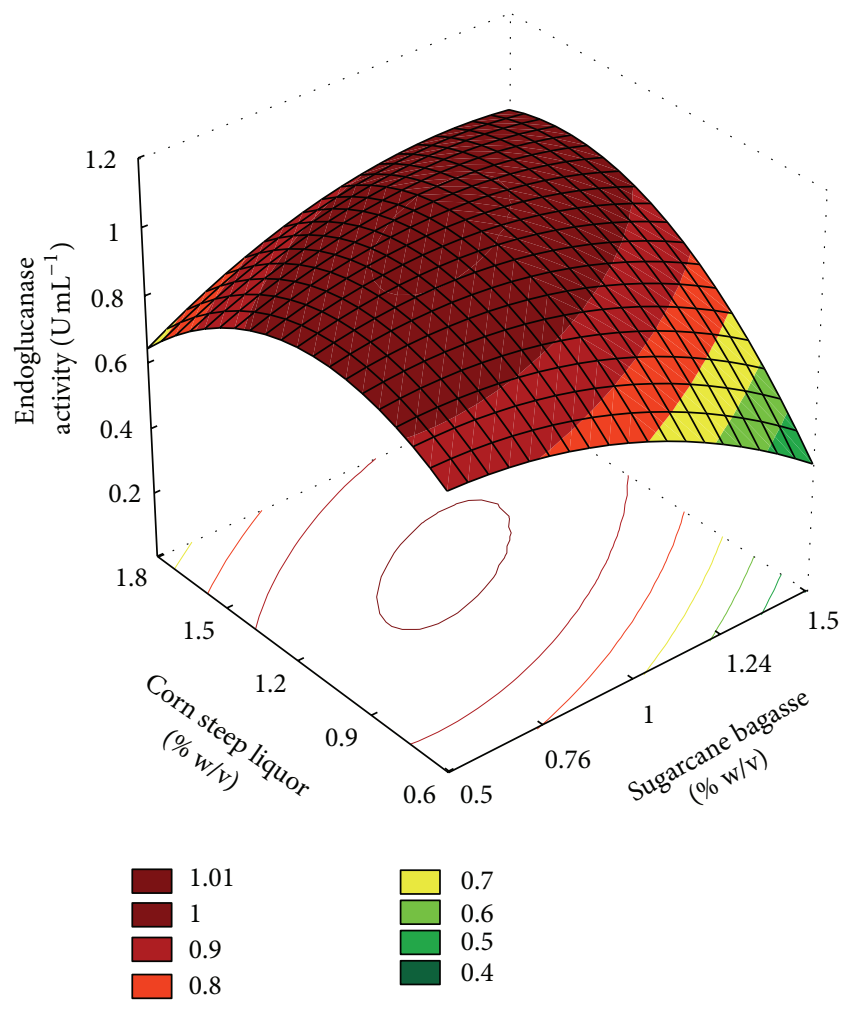

FIgURE 1: Response surface on endoglucanase production by Streptomyces misionensis PESB-25 using SCB and CSL concentrations as the independent variables.

the analysis of variance (ANOVA) (Table 2) have shown endoglucanase production as a function of the codified values of SCB and CSL. The equation that represented a suitable model for endoglucanase production $(Y)$ is given in:

$$
\begin{aligned}
Y= & 1.01-0.03^{*} \mathrm{SCB}-0.06^{*} \mathrm{SCB} 2+0.06^{*} \mathrm{CSL} \\
& -0.11^{*} \mathrm{CSL} 2+0.09^{*} \mathrm{SCB}^{*} \mathrm{CSL} \pm 0.024 .
\end{aligned}
$$

The model $F$ value of 11.74 implies that the model is significant at a high confidence level. The probability $P$ value was also very low $(<0.1)$ indicating the significance of the model. The lack of fit term was insignificant at $(\alpha=0.1)$.

The validation of the mathematical model used was performed in triplicates and confirmed the maximal values for endoglucanase activity obtained, from 0.9 to $1.04 \mathrm{U} \cdot \mathrm{mL}^{-1}$ when SCB $1.0 \%(\mathrm{w} / \mathrm{v})+$ CSL $1.2 \%(\mathrm{w} / \mathrm{v})$ were used.

According to the data presented in Table 3, maximum endoglucanase accumulation of $1.54 \mathrm{U} \cdot \mathrm{mL}^{-1}$ was observed at $66^{\circ} \mathrm{C}$ and $\mathrm{pH}$ 3.6. As expected, the enzyme levels were influenced by $\mathrm{pH}$ and temperature. Acidic conditions as well as higher temperatures favored endoglucanase activity. The analysis of the resulting surface response plots revealed that the maximal endoglucanase activity occurred in $\mathrm{pH}$ range of $3.0-3.6$ and temperature of $62.5-70^{\circ} \mathrm{C}$ (Figure 2).

The model was tested for adequacy by ANOVA (Table 4). The model $F$ value of 19.67 indicates that the model is significant at a high confidence level. The probability $P$ value was also very low $(<0.1)$ indicating the significance of the model.
TABLE 3: Observed and predicted values of endoglucanase activity for the independent variables $\mathrm{pH}$ and temperature used in CCRD, from the crude enzyme preparation of Streptomyces misionensis PESB-25.

\begin{tabular}{lcccc}
\hline Run & $\begin{array}{c}\mathrm{pH} / \text { Coded } \\
\text { level }\end{array}$ & $\begin{array}{c}\text { Temperature } \\
\left({ }^{\circ} \mathrm{C}\right) / \text { Coded } \\
\text { level }\end{array}$ & $\begin{array}{c}\text { Endoglucanase } \\
\text { activity } \\
\left(\mathrm{U} \cdot \mathrm{mL}^{-1}\right) \\
\text { Observed }\end{array}$ & $\begin{array}{c}\text { Endoglucanase } \\
\text { activity } \\
\left(\mathrm{U} \cdot \mathrm{mL}^{-1}\right) \\
\text { Predicted }\end{array}$ \\
\hline 1 & $3.6(-1)$ & $44(-1)$ & 1.02 & 0.96 \\
2 & $6.4(+1)$ & $44(-1)$ & 0.77 & 0.78 \\
3 & $3.6(-1)$ & $66(+1)$ & 1.53 & 1.42 \\
4 & $6.4(+1)$ & $66(+1)$ & 0.81 & 0.77 \\
5 & $3.0(-1.41)$ & $55(0)$ & 1.21 & 1.31 \\
6 & $7.0(1.41)$ & $55(0)$ & 0.72 & 0.72 \\
7 & $5.0(0)$ & $40(-1.41)$ & 0.78 & 0.79 \\
8 & $5.0(0)$ & $70(1.41)$ & 1.02 & 1.11 \\
9 & $5.0(0)$ & $55(0)$ & 1.27 & 1.23 \\
10 & $5.0(0)$ & $55(0)$ & 1.26 & 1.23 \\
11 & $5.0(0)$ & $55(0)$ & 1.18 & 1.23 \\
12 & $5.0(0)$ & $55(0)$ & 1.20 & 1.23 \\
\hline
\end{tabular}

TABLE 4: Statistical ANOVA for the model of endoglucanase activity at different levels of $\mathrm{pH}$ and temperature values.

\begin{tabular}{lccccc}
\hline $\begin{array}{l}\text { Source of } \\
\text { variation }\end{array}$ & $\begin{array}{c}\text { Sum of } \\
\text { squares }\end{array}$ & $\begin{array}{c}\text { Degrees of } \\
\text { freedom }\end{array}$ & $\begin{array}{c}\text { Mean } \\
\text { square }\end{array}$ & $F$ value & $\begin{array}{c}P \text { value } \\
(\text { prob }>F)^{b}\end{array}$ \\
\hline Model & 0.67 & 5 & 0.13 & 19.67 & 0.001 \\
Residual & 0.04 & 6 & 0.01 & & \\
Lack of Fit & 0.03 & 3 & 0.012 & 6.44 & 0.08 \\
Pure Error & 0.005 & 3 & 0.002 & & \\
\hline
\end{tabular}

Total $\quad 0.71 \quad 11$

${ }^{\mathrm{b}}$ Statistically significant at $95 \%$ of confidence level; $R^{2}=0.89$.

The coefficient of determination obtained $\left(R^{2}=0.895\right)$ indicates that $89.5 \%$ of the variability of the responses can be explained by the model.

The regression equations, obtained after the ANOVA, demonstrated endoglucanase activity as a function of the codified values of $\mathrm{pH}$ and temperature. The equation that represented a suitable model for endoglucanase activity $(Y)$ is given in:

$$
\begin{aligned}
Y= & 1.23-0.21^{*} \mathrm{pH}-0.11^{*} \mathrm{pH} 2+0.11^{*} \mathrm{~T} \\
& -0.14^{*} \mathrm{~T} 2-0.12^{*} \mathrm{pH}^{*} \mathrm{~T} \pm 0.04 .
\end{aligned}
$$

The graphic of response surface (Figure 2) suggests that other ranges should be studied, so a new CCRD was performed using new $\mathrm{pH}$ and temperature ranges (from 2.0 to 5.0 and $55^{\circ} \mathrm{C}$ to $85^{\circ} \mathrm{C}$ ), but the results were not an improvement. In this new matrix, the maximal endoglucanase activity was $1.30 \mathrm{U} \cdot \mathrm{mL}^{-1}$ at $\mathrm{pH} 4.6$ and $66^{\circ} \mathrm{C}$. In this case, the best temperature was the same as before, but the enzyme activity had decreased.

Based on the first CCRD experiment, a validation of the model was performed, using the best concentrations of $\mathrm{C}$ 


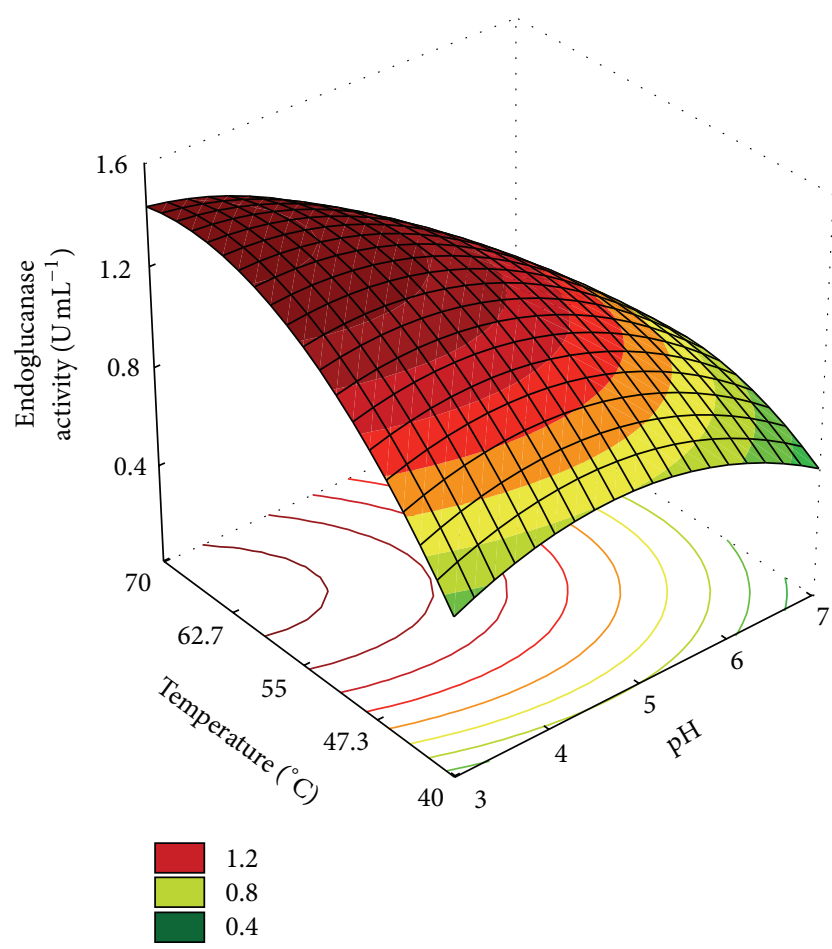

Figure 2: Response surface for Streptomyces misionensis PESB-25 endoglucanase activity by using $\mathrm{pH}$ and temperature values as the independent variables.

and $\mathrm{N}$ sources for enzymatic production [(SCB 1.0\% (w/v) and CSL $1.2 \%(\mathrm{w} / \mathrm{v})]$ and one of the $\mathrm{pH}$ and $T$ conditions suggested by model, $\mathrm{pH} 3.0$ and $70^{\circ} \mathrm{C}$, in triplicate. The results obtained were $1.54 \pm 0.01 \mathrm{U} \cdot \mathrm{mL}^{-1}$ of endoglucanase activity that represented an increase of $50 \%$ in endoglucanase activity in comparison to that observed at $\mathrm{pH} 4.8$ and $50^{\circ} \mathrm{C}$. Based on these results, we can conclude that Streptomyces misionensis PESB-25 produces a thermoacidophilic endoglucanase.

Cellulases with maximum activity at the acidic $\mathrm{pH}$ range are often observed for fungal enzymes [31] as well as for Streptomyces. As such, endoglucanase produced by $S$. malaysiensis AMT-3, S. viridobrunneus SCPE-09, S. drozdowiczii M7A, and Streptomyces sp. J2 presented maximal activity in the $\mathrm{pH}$ range from 4.0 to $6.0[8-10,32]$. However, optimum $\mathrm{pH}$ for the Streptomyces misionensis PESB-25 endoglucanase was determined as 3.0, which is noteworthy.

In general, the optimum temperature for endoglucanase activity for Streptomyces strains is around $50^{\circ} \mathrm{C}[8-10,33]$. Our strain showed maximum activity at $70^{\circ} \mathrm{C}$, a characteristic that differs from most other Streptomyces. Jaradat et al. [32] described an optimal endoglucanase activity at $60^{\circ} \mathrm{C}$, obtained from Streptomyces sp. J2, but as far as we are aware, there are no reports in the literature of an endoglucanase Streptomyces origin with optimal activity at such a high temperature. These unusual results concerning $\mathrm{pH}$ and temperature make our strain a very promising candidate for biotechnological applications, especially when very acidic and thermophilic conditions will be necessary.
TABLE 5: Effect of metal ions on endoglucanase activity. Enzyme was produced by $S$. misionensis PESB-25 grown on $1.0 \%(\mathrm{w} / \mathrm{v}) \mathrm{SCB}$ and $1.2 \%(\mathrm{w} / \mathrm{v})$ CSL.

\begin{tabular}{lcc}
\hline Ion $^{\text {a }}$ & $\begin{array}{c}\text { Relative activity } \\
(\%)^{*}\end{array}$ & $\begin{array}{c}\text { Endoglucanase activity } \\
\left(\mathrm{U} \cdot \mathrm{mL}^{-1}\right)\end{array}$ \\
\hline Control (no addition) & 100.0 & 1.72 \\
$\mathrm{NaCl}$ & $133.2 \pm 2.0$ & 2.23 \\
$\mathrm{CuSO}_{4}$ & $140.6 \pm 0.3$ & 2.30 \\
$\mathrm{MgSO}_{4}$ & $126.6 \pm 0.9$ & 2.18 \\
$\mathrm{CoSO}_{4}$ & $161.2 \pm 0.6$ & 2.73 \\
$\mathrm{MnSO}_{4}$ & $201.5 \pm 0.1$ & 3.48 \\
$\mathrm{FeSO}_{4}$ & $131.1 \pm 0.1$ & 2.34 \\
$\mathrm{CaCl}_{2}$ & $137.6 \pm 2.3$ & 2.25 \\
$\mathrm{KCl}^{\mathrm{BaCl}}$ & $125.3 \pm 4.9$ & 2.17 \\
\hline
\end{tabular}

${ }^{\mathrm{a}}$ The final concentration in the reaction mixture was $2 \mathrm{mM}$.

${ }^{*}$ Values are based on Mean \pm SD of 3 individual observations.

TABLE 6: Effect of different manganese concentrations on endoglucanase activity.

\begin{tabular}{lcc}
\hline $\begin{array}{l}\mathrm{Mn}^{2+} \\
\text { Concentration }^{\mathrm{a}}\end{array}$ & $\begin{array}{c}\text { Relative activity } \\
(\%)^{*}\end{array}$ & $\begin{array}{c}\text { Endoglucanase activity } \\
\left(\mathrm{U} \cdot \mathrm{mL}^{-1}\right)\end{array}$ \\
\hline Control (no addition) & 100.0 & 1.72 \\
$1 \mathrm{mM}$ & $182.2 \pm 1.5$ & 3.08 \\
$2 \mathrm{mM}$ & $201.5 \pm 0.08$ & 3.48 \\
$4 \mathrm{mM}$ & $185.4 \pm 9.0$ & 3.28 \\
$8 \mathrm{mM}$ & $243.0 \pm 5.7$ & 4.34 \\
$10 \mathrm{mM}$ & $233.7 \pm 1.6$ & 3.96 \\
\hline
\end{tabular}

${ }^{\mathrm{a}}$ Final Concentration in the reaction mixture.

${ }^{*}$ Values are based on Mean \pm SD of 3 individual observations.

Metal ions may be a requirement for enzymatic activity and might even be an integral component of the enzyme complex [34]. Ions may also be required as cofactors for their maximum activity [35]. According to Chauvaux et al. [36], manganese and other metal ions can enhance the substrate binding affinity of the enzyme and stabilize the conformation of the catalytic site. The results for the effect of several metal ions on endoglucanase activity of S. misionensis PESB-25 are shown in Table 5. None of the ions studied inhibited the enzyme activity at a concentration of $2 \mathrm{mM}$. The addition of $\mathrm{Ba}^{2+}$ resulted in a small increase in activity (9.3\%), which differs from the results reported by Grigorevski-Lima and colleagues [10], who showed that endoglucanase activity of $S$. drozdowiczii M7A greatly increased (86\%) in the presence of $\mathrm{Ba}^{2+}$. In these experiments, the addition of $\mathrm{Mn}^{2+}$ and $\mathrm{Co}^{2+}$ to the $S$. misionensis PESB-25 supernatant resulted in significant increases in endoglucanase activity (101.5 and 61.2\%, resp.).

Considering the significant effect of $\mathrm{Mn}^{2+} 2 \mathrm{mM}$ on endoglucanase activity, this effect was further evaluated. The results are shown in Table 6 and they show the effect of $\mathrm{Mn}^{2+}$ in the concentration range of 1 to $10 \mathrm{mM}$. This ion had a hyperactivating effect on endoglucanase, with 
maximum activity of $4.34 \mathrm{U} \cdot \mathrm{mL}^{-1}$ observed with $\mathrm{Mn}^{2+} 8 \mathrm{mM}$ which corresponded to an increase of $143 \%$ in endoglucanase activity in relation to when no $\mathrm{Mn}^{2+}$ was added.

Although studies dealing with the activation of cellulase activity by manganese in Streptomyces strains have not been previously reported, there is a report on the positive effect of this ion on Bacillus subtilis cellulase 5A [37]. Also some fungal cellulases are activated by $\mathrm{Mn}^{2+}$. Gao et al. [38] studied the influence of several metal ions on activity of a purified endoglucanases from Aspergillus terreus and found an increase of $43 \%$ when using $\mathrm{Mn}^{2+} 2 \mathrm{mM}$. Tao et al. [39], studying Aspergillus glaucus, found increments of $30 \%$ when the final concentration of $\mathrm{Mn}^{2+} 4 \mathrm{mM}$ was used for a purified endoglucanases obtained when growing the fungus in SCB medium. Manganese was also able to increase enzymatic activity of other enzymes, such as endonucleases from Penicillium chrysogenum PCL501, where an increase of $219.6 \%$ in presence of $\mathrm{Mn}^{2+} 2 \mathrm{mM}$ was observed [34].

Few articles have been published describing cellulase production by actinomycetes using agroindustrial residues as substrates, and most of them have given very low values for endoglucanase activity when using wheat straw (WS) $[40,41]$ or wheat bran (WB) [10] as the main substrate. Our group has obtained values of $0.71 \mathrm{U} \cdot \mathrm{mL}^{-1}$ when using brewer spent grain (BSG) [8], and more recently $2.00 \mathrm{U} \cdot \mathrm{mL}^{-1}$ when using wheat bran [9]. Values as high as $4.34 \mathrm{U} \cdot \mathrm{mL}^{-1}$, obtained in the present research, have not been described yet for endoglucanase production by actinomycetes using lowcost residues, especially SCB.

The results of the endoglucanase thermal stability are shown in Figure 3. When the enzyme crude extract was incubated at $65^{\circ} \mathrm{C}$, the enzyme activity decreased $70 \%$ of its initial activity within $15 \mathrm{~min}$ of incubation. However, upon incubation at $50^{\circ} \mathrm{C}$, activity decreased to $40 \%$ within $30 \mathrm{~min}$, retaining this activity for $2 \mathrm{~h}$. The enzyme half-life at $50^{\circ} \mathrm{C}$ was $4 \mathrm{~h}$.

It is known that metal ions play an important role in stabilizing proteins, protecting against thermal denaturation by binding at specific sites [36, 42]. Several studies have shown increased enzyme thermal stability in presence of calcium [27, 42, 43], which is known to regulate the stability and reactivity of a wide variety of biological proteins [43]. Given the strong positive effect of $\mathrm{Mn}^{2+}$ on endoglucanase activity, the effect of this ion on the enzyme stability was further investigated. It was observed that in the presence of $\mathrm{Mn}^{2+} 8 \mathrm{mM}$, the crude enzyme preparation increased $25 \%$ of its initial activity upon incubation for $30 \mathrm{~min}$ at $65^{\circ} \mathrm{C}$, and when $\mathrm{Mn}^{2+} 16 \mathrm{mM}$ was used, the activity increased to over $70 \%$. Moreover, at a manganese ion concentration of $16 \mathrm{mM}$, the enzyme half-life at $65^{\circ} \mathrm{C}$ was almost 2 hours.

Results from enzyme stability at $50^{\circ} \mathrm{C}$ were even more promising. The incubation of crude extract with $\mathrm{Mn}^{2+}$ at final concentration of $16 \mathrm{mM}$ resulted in an increase in thermal stability of $40 \%$ after 4 hours incubation (Figure 3 ), in comparison to the results for the experiments in the absence of the ion. Activity retention of over $92 \%$ for $5 \mathrm{~h}$,

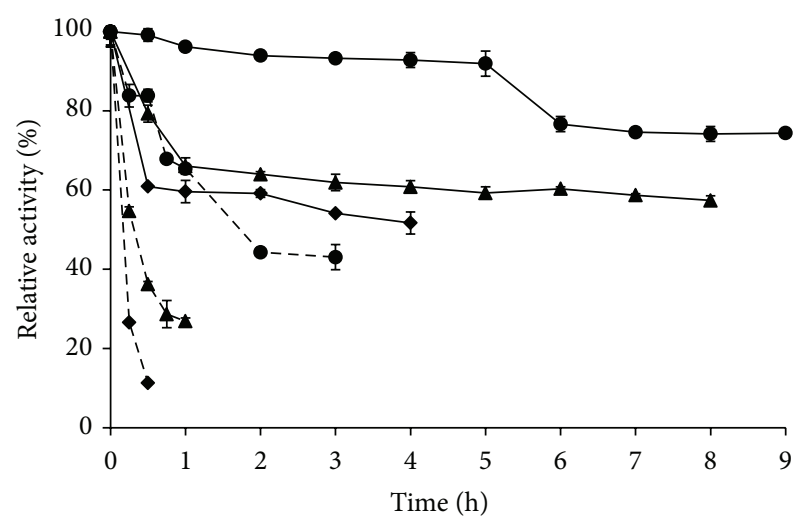

FIgure 3: Thermal stability of Streptomyces misionensis PESB-25 endoglucanase activity at $65^{\circ} \mathrm{C} \mathrm{(--)}$ and $50^{\circ} \mathrm{C}(-)$ : crude extract (filled diamond), crude extract $+\mathrm{MnSO}_{4} 8 \mathrm{mM}$ (filled triangle), and crude extract $+\mathrm{MnSO}_{4} 16 \mathrm{mM}$ (filled circle). Residual activity is expressed as a percentage of the original activity. Error bars represent one standard deviation of each experimental point $(n=3)$.

and over $70 \%$ after $9 \mathrm{~h}$ of incubation, shows beyond doubt the positive effect of $\mathrm{Mn}^{2+} 16 \mathrm{mM}$ on the enzyme structural stabilization. According to the overall results, incubation of the crude extract with $\mathrm{Mn}^{2+}$ at $50^{\circ} \mathrm{C}$ increased the half-life of the enzyme from $4 \mathrm{~h}$ (no $\mathrm{Mn}^{2+}$ addition) to more than $8 \mathrm{~h}$ (addition of $\mathrm{Mn}^{2+} 8 \mathrm{mM}$ ) or even more than $30 \mathrm{~h}$ (addition of $\mathrm{Mn}^{2+} 16 \mathrm{mM}$ ). Values of half-lives of $8 \mathrm{~h}$ have been currently reported in the literature for Streptomyces strains $[9,10]$.

These are very promising results for the Streptomyces misionensis endoglucanase. Its natural thermal stability (which can be significantly enhanced with manganese) indicates potential as a biocatalyst for industrial process that demands long processing times at elevated temperatures, such as those in the food, sugar, and fuel ethanol industries [33]. Also, additional studies for the determination of its stability at different $\mathrm{pH}$ values and different periods of time would be interesting for future industrial applications.

The zymogram analysis of the culture supernatant of Streptomyces misionensis PESB-25 is shown in Figure 4. Three protein bands with endoglucanase activity and estimated molecular masses of $12.0,48.5$ and $119.5 \mathrm{kDa}$ are clearly shown. Cellulose degrading microorganisms commonly produce multienzyme systems [44]. As such, and in accordance to previous reports, Nascimento and colleagues [8] observed three cellulolytic bands $(51,115$, and $178 \mathrm{kDa})$ in the supernatants of S. malaysiensis AMT-3 when BSG 0.5\% (w/v) and CSL $1.2 \%(w / v)$ were used. Da Vinha et al. [9], in their study, cultured Streptomyces viridobrunneus SCPE-09 in 2.0\% wheat bran (w/v) and $0.19 \%$ CSL (w/v). In these conditions, two bands of endoglucanase activity were observed, one with estimated molecular masses of 37 and the other with $119 \mathrm{kDa}$.

Additional studies about these enzymes are required to better evaluate their feasibility for further industrial applications. Purification would enable kinetics studies and also the determination of their specific activity. 


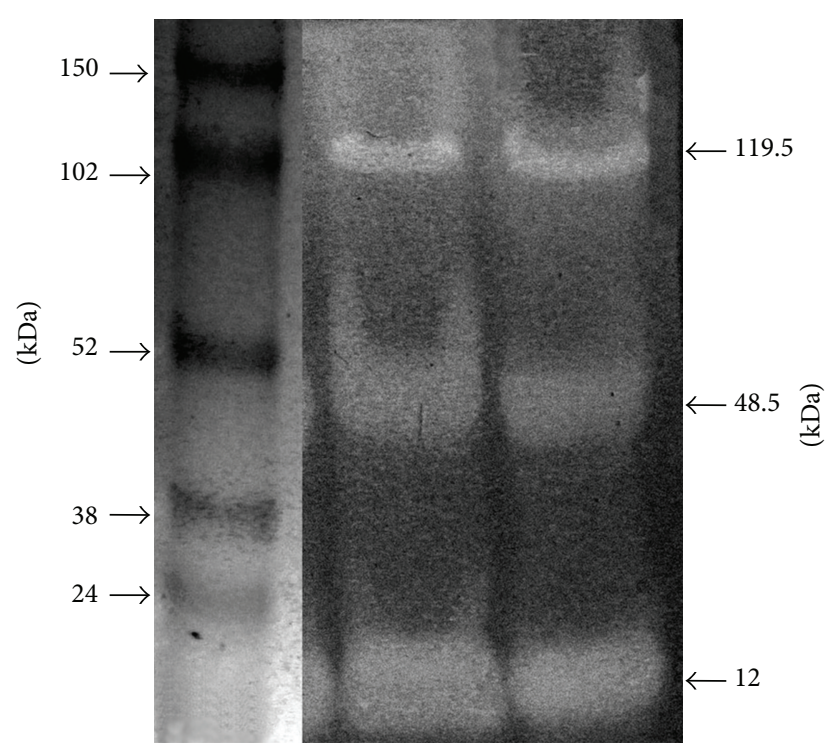

Figure 4: Zymogram analysis (duplicate experiment) of the culture supernatant of $S$. misionensis PESB-25 showing three bands with endoglucanase activity. Cells were grown on SCB $1.0 \%(\mathrm{w} / \mathrm{v})$ and CSL $1.2 \%(\mathrm{w} / \mathrm{v})$. The calculated molecular masses (in $\mathrm{kDa}$ ) of the endoglucanases are indicated on the right side of the figure. The molecular masses of the markers Full-Range Rainbow (GE-RPN $800 \mathrm{E}$ ) are indicated on the left side of the figure. For details see text.

\section{Conclusions}

In this study, S. misionensis PESB-25 was able to grow and produce endoglucanase in a culture medium containing a salt solution and agroindustrial by-products, specifically sugarcane bagasse and corn steep liquor, as the main carbon and nitrogen substrates. Characterization of the crude enzyme showed that the endoglucanases produced were acidic, thermophilic, and thermotolerant. An optimum $\mathrm{pH}$ of 3.0 was reported which is rare. An optimum activity temperature at $70^{\circ} \mathrm{C}$ was seen and is novel for actinobacterial strains. The activity of these endoglucanases was also strongly increased and more stable in the presence of a number of metal ions, especially $\mathrm{Mn}^{2+}$. Activity of $4.34 \mathrm{U} \cdot \mathrm{mL}^{-1}$ was obtained under these conditions. This level of activity places this study amongst the highest described in the literature for cellulase production by Streptomyces strains using low-cost residues as substrates. The effect of $\mathrm{Mn}^{+2} 16 \mathrm{mM}$ on enzyme stability was also important and noteworthy. Manganese at that concentration increased the enzyme stability half-life from less than $4 \mathrm{~h}$ to greater than $30 \mathrm{~h}$ at $50^{\circ} \mathrm{C}$ and from less than 30 minutes to $2 \mathrm{~h}$ at $65^{\circ} \mathrm{C}$.

The characteristics of thermoacidophiles, thermal stability, and induction by manganese suggest that endoglucanases from S. misionensis PESB-25 could be considered as promising alternatives in biotechnological applications. For example they could be used as a complement to fungal enzymatic mixtures improving the lignocellulose hydrolysis for ethanol production. Combining advantageous enzyme characteristics with the use of low-cost residues (SCB and CSL), we have the potential for a new low-cost enzyme production process.

\author{
Abbreviations \\ ANOVA: Analysis of variance \\ BLAST: Basic local alignment search tool \\ BSG: Brewer spent grain \\ CCRD: Central composite rotational design \\ $\mathrm{CMC}_{\mathrm{lw}}$ : Carboxymethylcellulose low viscosity \\ CSL: Corn steep liquor \\ NCBI: National center for biotechnology information \\ RDP: Ribosomal database project \\ RSM: Response surface methodology \\ SCB: $\quad$ Sugarcane bagasse \\ SDS: $\quad$ Sodium dodecyl sulphate \\ WB: Wheat bran \\ WS: Wheat straw.
}

\section{Acknowledgments}

This work was supported by grants from the Conselho Nacional de Desenvolvimento Científico e Tecnológico (CNPq), Coordenação de Aperfeiçoamento de Pessoal do Ensino Superior (CAPES), and Financiadora de Estudos e Projetos (FINEP). The authors also thank the Postgraduate Programme in Plant Biotechnology (Programa de pós-graduação em Biotecnologia Vegetal) and Postgraduate Programme in Science, Microbiology (Programa de posgraduação em Ciências, Microbiologia) at Universidade Federal do Rio de Janeiro (UFRJ).

\section{References}

[1] J. Kim, S. Yun, and Z. Ounaies, "Discovery of cellulose as a smart material," Macromolecules, vol. 39, no. 12, pp. 4202-4206, 2006.

[2] P. Béguin and J. P. Aubert, "The biological degradation of cellulose," FEMS Microbiology Reviews, vol. 13, no. 1, pp. 25-28, 1994.

[3] J. Liu, W. D. Liu, X. L. Zhao, W. J. Shen, H. Cao, and Z. L. Cui, "Cloning and functional characterization of a novel endo- $\beta$ 1,4- glucanase gene from a soil-derived metagenomic library," Applied Microbiology and Biotechnology, vol. 89, no. 4, pp. 10831092, 2011.

[4] S. L. Liu and M. Xing, "Purification, properties and mass spectrometry analysis of two novel thermotolerant endoglucanases from Bacillus akibai I-2," Advanced Materials Research, vol. 393395, pp. 911-915, 2012.

[5] J. Lacey, "Actinomycetes in composts," Annals of Agricultural and Environmental Medicine, vol. 4, pp. 113-121, 1997.

[6] C. S. Park, T. Kawaguchi, J. I. Sumitani, G. Takada, K. Izumori, and M. Arai, "Cloning and sequencing of an exoglucanase gene from Streptomyces sp. M23, and its expression in Streptomyces lividans TK-24," Journal of Bioscience and Bioengineering, vol. 99, no. 4, pp. 434-436, 2005.

[7] F. Alani, W. A. Anderson, and M. Moo-Young, "New isolate of Streptomyces sp. with novel thermoalkalotolerant cellulases," Biotechnology Letters, vol. 30, no. 1, pp. 123-126, 2008.

[8] R. P. Nascimento, N. A. Junior, N. Pereira, E. P. S. Bon, and R. R. R. Coelho, "Brewer's spent grain and corn steep liquor as substrates for cellulolytic enzymes production by Streptomyces malaysiensis," Letters in Applied Microbiology, vol. 48, no. 5, pp. 529-535, 2009. 
[9] F. N. M. Da Vinha, M. P. Gravina-Oliveira, M. N. Franco et al., "Cellulase production by Streptomyces viridobrunneus SCPE09 using lignocellulosic biomass as inducer substrate," Applied Biochemistry and Biotechnology, vol. 164, no. 3, pp. 256-267, 2011.

[10] A. L. Grigorevski-Lima, R. P. Nascimento, E. P. S. Bon, and R. R. R. Coelho, "Streptomyces drozdowiczii cellulase production using agro-industrial by-products and its potential use in the detergent and textile industries," Enzyme and Microbial Technology, vol. 37, no. 2, pp. 272-277, 2005.

[11] A. Sazci, A. Radford, and K. Erenler, "Detection of cellulolytic fungi by using Congo red as an indicator: a comparative study with the dinitrosalicyclic acid reagent method," Journal of Applied Bacteriology, vol. 61, no. 6, pp. 559-562, 1986.

[12] D. A. Hopwood, M. J. Bibb, K. F. Chater et al., Genetic Manipulation of Streptomyces: A Laboratory Manual, The John Innes Institute, Norwich, UK, 1985.

[13] E. B. Shirling and D. Gottlieb, "Methods for characterization of Streptomyces species," International Journal of Systematic Bacteriology, vol. 16, no. 3, pp. 313-340, 1966.

[14] C. P. Kurtzman and C. J. Robnett, "Identification and phylogeny of ascomycetous yeasts from analysis of nuclear large subunit (26S) ribosomal DNA partial sequences," Antonie van Leeuwenhoek, vol. 73, no. 4, pp. 331-371, 1998.

[15] H. Hayashi, M. Sakamoto, and Y. Benno, "Evaluation of three different forward primers by terminal restriction fragment length polymorphism analysis for determination of fecal Bifidobacterium spp. in healthy subjects," Microbiology and Immunology, vol. 48, no. 1, pp. 1-6, 2004.

[16] F. E. Löffler, Q. Sun, J. Li, and J. M. Tiedje, "16S rRNA genebased detection of tetrachloroethene-dechlorinating Desulfuromonas and Dehalococcoides species," Applied and Environmental Microbiology, vol. 66, no. 4, pp. 1369-1374, 2000.

[17] J. R. Cole, Q. Wang, E. Cardenas et al., "The ribosomal database project: improved alignments and new tools for rRNA analysis," Nucleic Acids Research, vol. 37, no. 1, pp. D141-D145, 2009.

[18] D. A. Benson, I. Karsch-Mizrachi, D. J. Lipman, J. Ostell, and D. L. Wheeler, “GenBank," Nucleic Acids Research, vol. 36, no. 1, pp. D25-D30, 2008.

[19] M. Johnson, I. Zaretskaya, Y. Raytselis, Y. Merezhuk, S. McGinnis, and T. L. Madden, "NCBI BLAST: a better web interface," Nucleic Acids Research, vol. 36, pp. W5-W9, 2008.

[20] G. J. M. Rocha, F. T. Silva, G. T. Araújo, and A. A. S. Curvelo, "A fast and accurate method for determination of cellulose and polyoses by HPLC," in Proceedings of the 5th Brazilian symposium on chemistry of lignins and other wood components, vol. 6, pp. 3-8, Curitiba, Brazil, 1997.

[21] L. E. R. Paula, P. F. Trugilho, A. Napoli, and M. L. Bianchi, "Characterization of residues from plant biomass for use in energy generation," CERNE, vol. 17, no. 2, pp. 237-246, 2011.

[22] The Corn Refiners Association, "Assessment plan for corn steep liquor (CAS no. 66071-94-1) in accordance with the USEPA high production," volume chemical challenge program prepared for November 2006.

[23] J. D. Breccia, G. R. Castro, M. D. Baigori, and F. Sineriz, "Screening of xytanolytic bacteria using a colour plate method," Journal of Applied Bacteriology, vol. 78, no. 5, pp. 469-472, 1995.

[24] L. Miller, "Use of dinitrosalicyllc acid reagent for determination of reducing sugars," Analytical Chemistry, vol. 31, pp. 426-428, 1959.

[25] T. K. Ghose, "Measurement of cellulase activities," Pure and Applied Chemistry, vol. 59, no. 2, pp. 257-268, 1987.
[26] G. Gomori, "General preparative procedures," in Methods in Enzymology, vol. 1, pp. 138-146, Academic Press, New York, NY, USA, 1955.

[27] T. César and V. Mrsa, "Purification and properties of the xylanase produced by Thermomyces lanuginosus," in Enzyme and Microbial Technology, vol. 19, pp. 289-296, 1996.

[28] A. P. Cercos, B. L. Eilberg, J. G. Goyena, J. Souto, E. E. Vautier, and I. Widuczynski, "Misionina: antibiotico polienico producido por Streptomyces misionensis n. sp," Revista de Investigaciones Agricolas, vol. 17, pp. 5-27, 1962.

[29] G. Garau, P. Castaldi, L. Santona, P. Deiana, and P. Melis, "Influence of red mud, zeolite and lime on heavy metal immobilization, culturable heterotrophic microbial populations and enzyme activities in a contaminated soil," Geoderma, vol. 142, no. 1-2, pp. 47-57, 2007.

[30] R. F. Seipke, J. Barke, M. X. Ruiz-Gonzalez, J. Orivel, D. W. Yu, and M. I. Hutchings, "Fungus-growing Allomerus ants are associated with antibiotic-producing actinobacteria," Antonie van Leeuwenhoek, pp. 1-5, 2011.

[31] A. L. Grigorevski-Lima, F. N. M. Da Vinha, D. T. Souza et al., "Aspergillus fumigatus thermophilic and acidophilic endoglucanases," Applied Biochemistry and Biotechnology, vol. 155, no. 1-3, pp. 321-329, 2009.

[32] Z. Jaradat, A. Dawagreh, Q. Ababneh, and S. Ismail, "Influence of culture conditions on cellulase production by Streptomyces sp. (strain J2)," Jordan Journal of Biological Science, vol. 1, no. 4, pp. 141-146, 2008.

[33] H. D. Jang and K. S. Chen, "Production and characterization of thermostable cellulases from Streptomyces transformant T3-1," World Journal of Microbiology and Biotechnology, vol. 19, no. 3, pp. 263-268, 2003.

[34] S. N. Chinedu, C. O. Nwinyi, and V. I. Okochi, "Properties of endoglucanase of Penicillium chrysogemum PCL501," Australian Journal of Basic and Applied Science, vol. 2, pp. 738-746, 2008.

[35] S. K. Soni, N. Batra, N. Bansal, and R. Soni, "Bioconversion of sugarcane bagasse into second generation bioethanol after enzymatic hydrolysis with in-house produced cellulases from Aspergillus sp. S4B2F," BioResources, vol. 5, no. 2, pp. 741-757, 2010.

[36] S. Chauvaux, H. Souchon, P. M. Alzari, P. Chariot, and P. Beguin, "Structural and functional analysis of the metal-binding sites of Clostridium thermocellum endoglucanase CelD," Journal of Biological Chemistry, vol. 270, no. 17, pp. 9757-9762, 1995.

[37] C. R. Santos, J. H. Paiva, M. L. Sforça et al., "Dissecting structure-function-stability relationships of a thermostable GH5-CBM3 cellulase from Bacillus subtilis 168," Biochemistry Journal, vol. 441, no. 1, pp. 95-104, 2012.

[38] J. Gao, H. Weng, Y. Xi, D. Zhu, and S. Han, "Purification and characterization of a novel endo- $\beta$-1,4-glucanase from the thermoacidophilic Aspergillus terreus," Biotechnology Letters, vol. 30, no. 2, pp. 323-327, 2008.

[39] Y.-M. Tao, X.-Z. Zhu, J.-Z. Huang et al., "Purification and properties of endoglucanase from a sugar cane bagasse hydrolyzing strain, Aspergillus glaucus XC9," Journal of Agricultural and Food Chemistry, vol. 58, no. 10, pp. 6126-6130, 2010.

[40] B. Godden, T. Legon, P. Helvenstein, and M. Penninckx, "Regulation of the production of hemicellulolytic and cellulolytic enzymes by a Streptomyces sp. growing on lignocellulose," Journal of General Microbiology, vol. 135, no. 2, pp. 285-292, 1989.

[41] M. Tuncer, A. Kuru, M. Isikli, N. Sahin, and F. G. Çelenk, "Optimization of extracellular endoxylanase, endoglucanase 
and peroxidase production by Streptomyces sp. F2621 isolated in Turkey," Journal of Applied Microbiology, vol. 97, no. 4, pp. 783-791, 2004.

[42] M. W. Pantoliano, M. Whitlow, J. F. Wood et al., "The engineering of binding affinity at metal ion binding sites for the stabilization of proteins: subtilisin as a test case," Biochemistry, vol. 27, no. 22, pp. 8311-8317, 1988.

[43] A. Tanaka and E. Hoshino, "Calcium-binding parameter of Bacillus amyloliquefaciens $\alpha$-amylase determined by inactivation kinetics," Biochemical Journal, vol. 364, no. 3, pp. 635-639, 2002.

[44] T. Dutta, R. Sahoo, R. Sengupta, S. S. Ray, A. Bhattacharjee, and S. Ghosh, "Novel cellulases from an extremophilic filamentous fungi Penicillium citrinum: production and characterization," Journal of Industrial Microbiology \& Biotechnology, vol. 35, no. 4, pp. 275-282, 2008. 

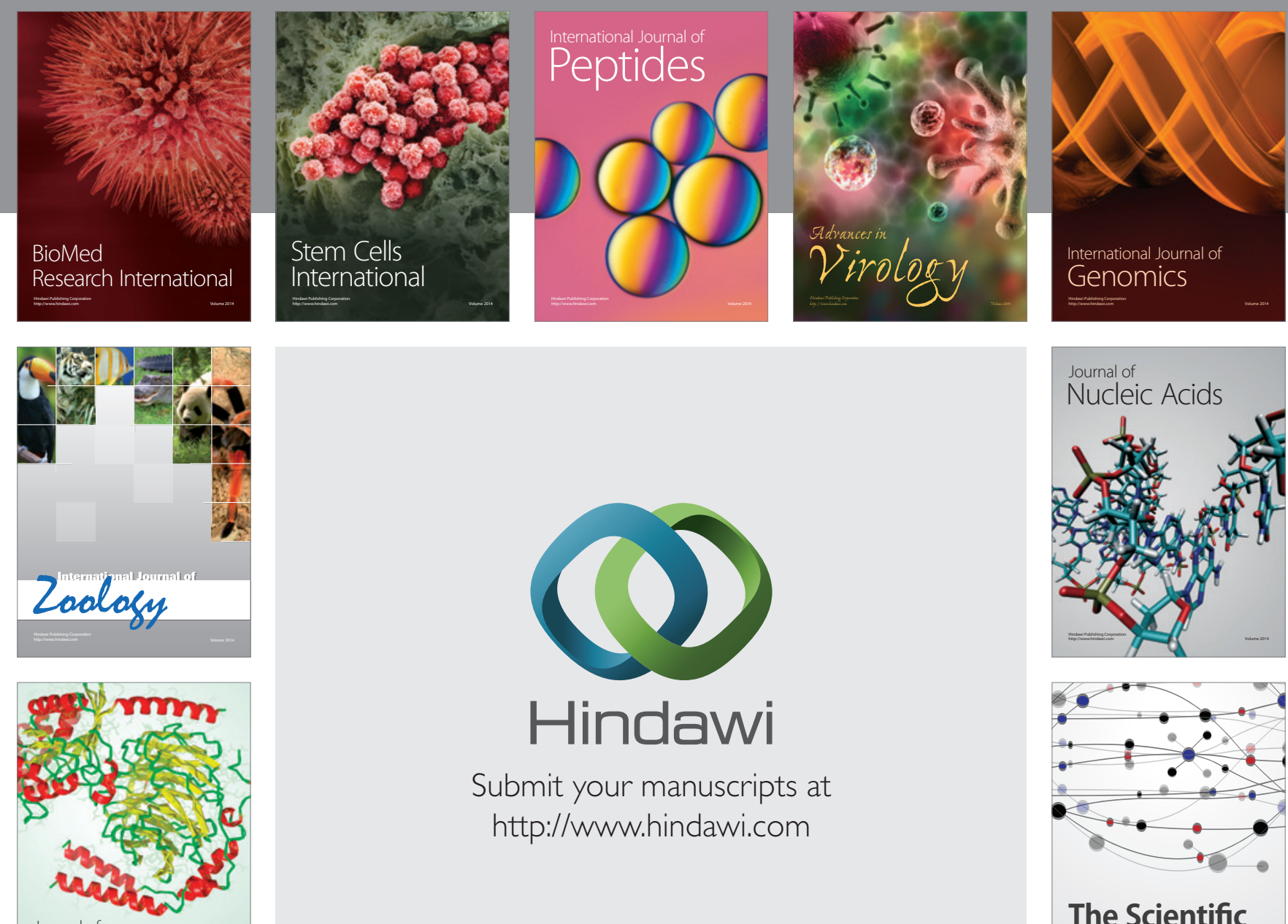

Submit your manuscripts at

http://www.hindawi.com

Journal of
Signal Transduction
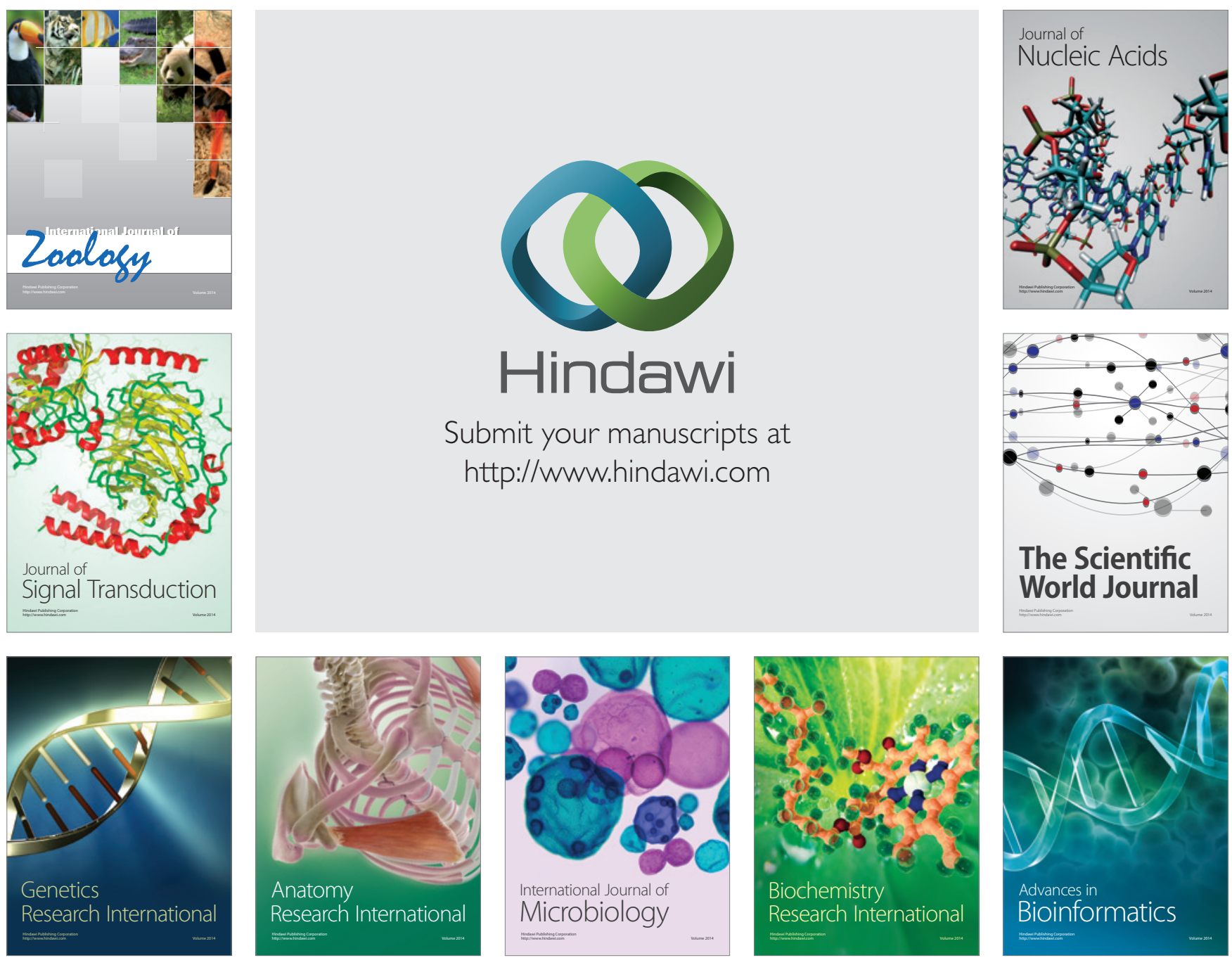

The Scientific World Journal
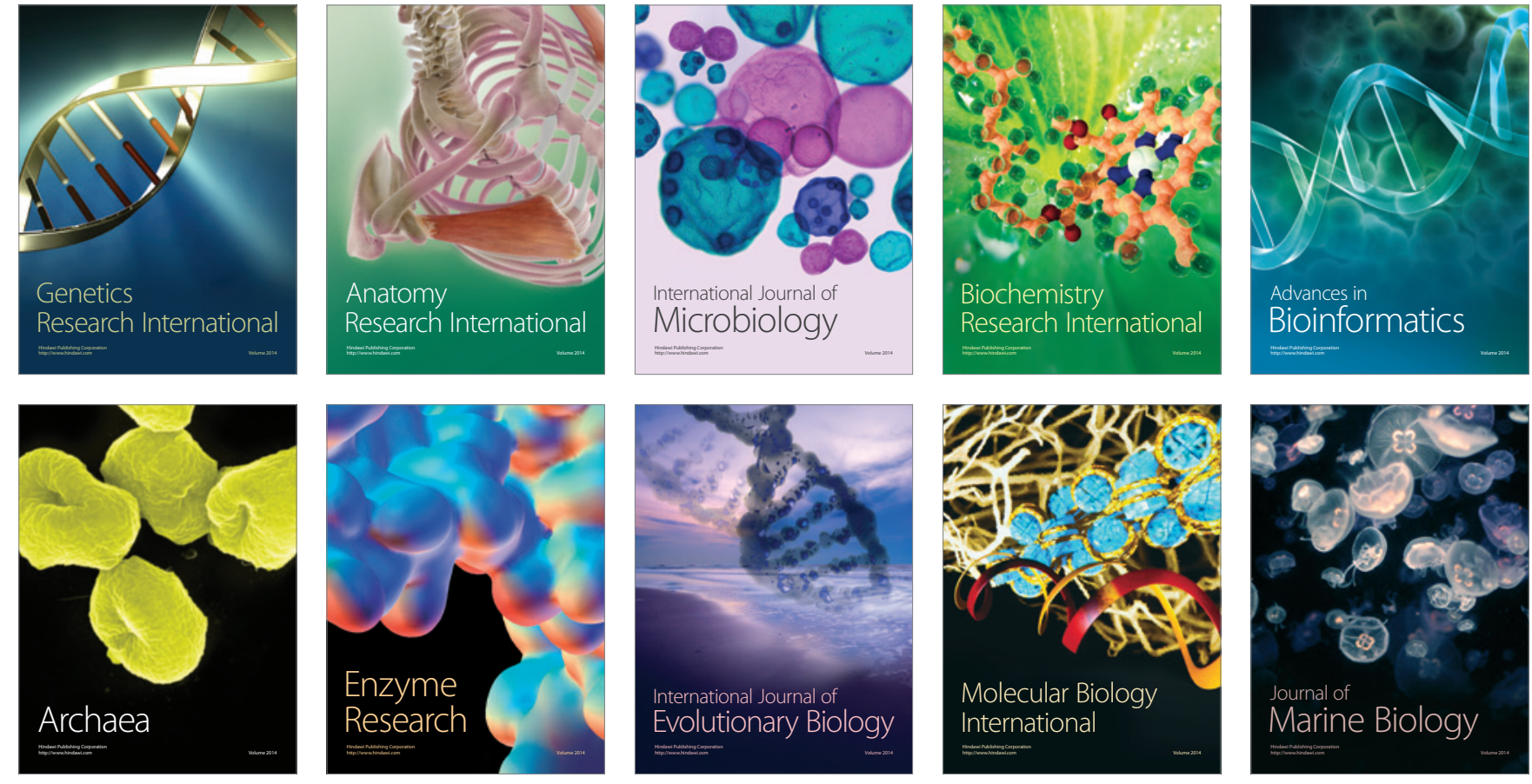